Tạp chí Khoa học và Công nghệ biển T11 (2011). Số 2. Tr 35 - 47

\title{
KHẢ NĂNG ẢNH HƯởNG CỦA Ô NHIẼ̃M DẦU ĐẾN CÁC RẠN SAN HÔ Ở MộT SỐ KHU VỰC VEN BIỂN VIỆT NAM
}

\author{
NGUYẼ̃N ĐĂNG NGẢI \\ Viện Tài nguyên và Môi trường biển
}

\begin{abstract}
Tóm tắt: Ở nhũ̃ng khu vục nghiên cứu (Ha Long, Cù Lao Chàm, Phú Quốc) có nồng độ dầu luôn ở mức cao, vuợt giới hạn cho phép (theo QCVN 10:2008) tù 1,3 đến 19 lần. Nhu vậy, nhũng vùng biển này đã có biểu hiện của sụ ô nhiễm dầu và tác động trục tiếp đến đời sống của các sinh vật thủy sinh. Sự suy giảm số luợng loài, độ phủ và phân bố của san hô đã diê̂n ra trong nhüng năm gần đây có thể có liên quan đến mức độ ô nhiễm dầu. Sau sự cố tràn dầu năm 2007 ở khu vưc Cù Lao Chàm, nồng độ dầu trong nuớc cao lên đột biến làm cho các rạn san hô thay đổi hẳn về cấu trúc, số luợng loài và độ phủ. Sụ suy giảm của san hô cũng theo sư biến thiên của nồng độ dầu trong nuớc, ở nhũng khu vưc gần cảng, bến tầu nồng độ dầu cao, độ phủ san hô giảm; càng ra xa cảng, nồng độ dầu càng giảm dần, quần xã san hô có xu thế tốt hơn.
\end{abstract}

\section{MỞ ĐÀ̀U}

Từ khi được phát hiện đến nay, dầu mỏ đã và đang là nguồn nguyên liệu vô cùng quý giá của mỗi Quốc gia nói riêng và toàn nhân loại nói chung. Ngày nay sản phẩm của dầu mỏ đang có mặt trong hầu hết các lĩnh vực đời sống sinh hoạt hàng ngày của con người cũng như trong hoạt động các ngành công nghiệp. Theo số liệu thống kê thì có khoảng 65 đến $70 \%$ năng lượng được sử dụng từ dầu mỏ, chỉ có khoảng 20 đến $22 \%$ từ than, 5 đến $6 \%$ từ năng lượng nước và 8 đến $12 \%$ từ năng lượng hạt nhân (Ngọ, 2010). Việc thăm dò và khai thác dầu khí đã và đang diễn ra mạnh nhất trong 1 - 2 thập kỷ qua do nhu cầu năng lượng ngày càng tăng, trong khi nguồn dầu mỏ càng cạn kiệt. Đồng hành với việc khai thác là công đoạn vận chuyển dầu đến các nhà máy lọc dầu và đến nơi tiêu thụ. Qua mỗi công đoạn đó thì nguy cơ gây ra sự cố tràn dầu ngoài ý muốn của con người thường xảy ra và gây ô nhiễm môi trường. Các phương tiện tiêu thụ dầu hoạt động trên biển cũng làm ô nhiễm môi trường nghiêm trọng đặc biệt là những phương tiện có công nghệ lạc hậu, quá niên hạn sử dụng. Có thể thấy rõ nhất tại các bến cảng, bến tàu nơi tập trung số lượng tàu thuyền lớn, các váng dầu nổi trên mặt nước theo dòng chảy, gió phát tán khắp nơi càng làm tăng diện tích ô nhiễm. Ở Việt nam mỗi năm xảy ra đến gần chục vụ tràn dầu trên biển gây thiệt hại to lớn về vật chất và môi trường, sức khỏe con người, 
cây trồng, vật nuôi... Tuy nhiên những thiệt hại đến các hệ sinh thái dưới nước thường ít được chú ý vì những biểu hiện của chúng không rõ ràng và khó nhìn thấy, nhưng những hậu quả để lại rất lớn và kéo dài. Khi sự cố ô nhiễm dầu xảy ra dầu sẽ nổi trên mặt nước gây cản trở sự trao đổi khí giữa nước và không khí làm môi trường nước trở nên thiếu ôxy đồng thời dầu còn gây độc cho các loài sinh vật dưới nước dẫn đến chúng bị chết nhanh chóng. Các loài nhạy cảm như san hô rất dễ bị tác động do chúng không có khả năng di chuyển, đặc biệt ô nhiễm dầu vào lúc thấp triều, dầu sẽ bám trực tiếp lên san hô nên mức độ tác động lớn hơn rất nhiều.

Trong nội dung bài báo này, tác giả sẽ trình bày một phần kết quả nghiên cứu của đề tài "Xây dưng cơ sở khoa học, pháp lý cho việc đánh giá và đòi bồi thường thiệt hại do ô nhiếm dầu gây ra trên vùng biển Việt Nam" về tác động của ô nhiễm dầu đến các rạn san hô vùng biển nước ta.

\section{II. ĐỊA ĐIỂM, TÀI LIỆU VÀ PHƯƠNG PHÁP NGHIÊN CÚU}

\section{1. Địa điểm và tài liệu nghiên cứu}

\section{Địa điểm}

Để nghiên cứu khả năng ảnh hưởng của ô nhiễm dầu đến các rạn san hô, 3 khu vực được lựa chọn đều có các rạn san hô phát triển và đại diện cho cả 3 miền Bắc, Trung, Nam là vịnh Hạ Long (Quảng Ninh), Cù Lao Chàm (Quảng Nam) và Phú Quốc (Kiên Giang), đồng thời các khu vực này đều có các bến cảng, số lượng tàu thuyền hoạt động nhiều hoặc thường xuyên chịu ảnh hưởng của sự cố tràn dầu (hình 1).

\section{Tài liệu}

Báo cáo được hình thành trên cơ sở thu thập và xử lý các kết quả nghiên cứu về san hô và rạn san hô tại các khu vực nghiên cứu từ trước đến nay của Viện Tài nguyên và Môi trường biển, Viện Hải dương học Nha Trang và WWF và các kết quả khảo sát năm 2009 và 2010 của tại các địa điểm nêu trên.

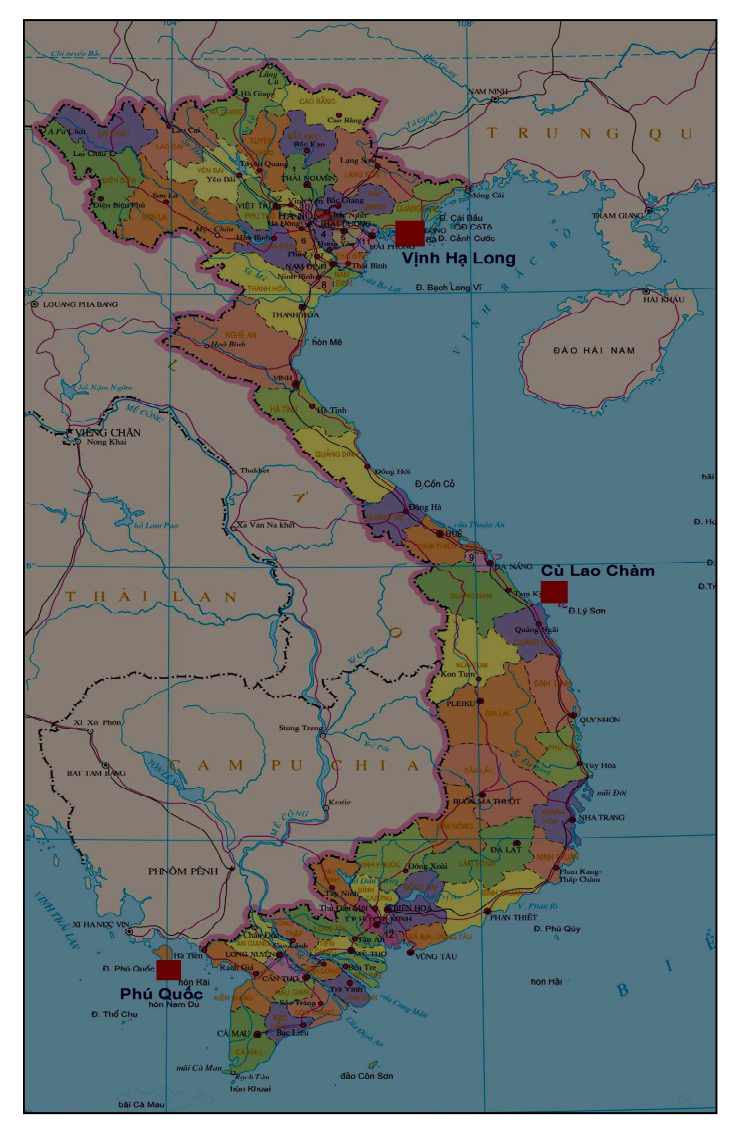

Hình 1: Địa điểm nghiên cứu 


\section{Phương pháp khảo sát ngoài hiện trường}

Các mẫu dầu mỡ được thu theo mặt cắt từ nơi phát tán (cảng, bến tàu...) ra xa (theo sự phân bố của san hô), mẫu được lấy 2 tầng mặt và đáy, được cố định và bảo quản lạnh, phân tích bằng máy quang phổ kế DR/2000 (HACH, USA). Áp dụng các phương pháp khảo sát rạn san hô đã được sử dụng rộng rãi trên Thế giới như khung định lượng, mặt cắt điểm (Reefcheck). Trong quá trình điều tra thu mẫu đã sử dụng các thiết bị lặn Scuba thu mẫu ở độ sâu tới trên 15 m. Dùng máy quay phim , máy chụp ảnh ngầm để ghi lại những hình ảnh của tất cả những sinh vật sống trên rạn. Những loài khó xác định được thu mẫu và phân tích trong phòng thí nghiệm.

\section{Phương pháp nghiên cứu trong phòng thí nghiệm}

- Trên cơ sở các tài liệu thu thập được tập hợp các kết quả nghiên cứu có liên quan, sử dụng biện pháp so sánh theo các điểm thời gian.

- Các mẫu vật, hình ảnh thu được trong các chuyến khảo sát được phân tích dựa vào tài liệu phân loại san hô sống của Veron (2000) và cấu trúc bộ xương của Veron et al. (1976, 1977, 1980, 1982, 1984).

- Xác định mức độ tác động của dầu lên rạn san hô, dựa trên cơ sở so sánh mức độ biến đổi nồng độ dầu trong nước tương quan với mức độ phát triển của rạn.

- Các số liệu hiện trường và kết quả phân tích trong phòng thí nghiệm được xử lý trên các phần mền MS. Excel, Word.

\section{KẾT QUẢ NGHIÊN CÚU}

\section{Tác động của ô nhiễm dầu đến rạn san hô khu vực Hạ Long}

Khu vực vịnh Hạ Long là nơi có sự ô nhiễm dầu khá cao, nguồn gây ô nhiễm chủ yếu do các hoạt động của tàu thuyền (tàu du lịch, tàu vận tải và tàu khai thác hải sản) đồng thời trong khu vực có các cảng bốc dỡ hàng hóa, cảng du lịch và đặc biệt có cảng xăng dầu B12. Nước trong vịnh Hạ Long kém lưu thông với môi trường biển do bị bao bọc che chắn bởi gần 2000 hòn đảo, do vậy lượng dầu rò rỉ ra môi trường tồn lưu lâu hơn và khả năng khuếch tán vào trong môi trường nước và trầm tích lớn hơn. Các kết quả khảo sát và quan trắc của Viện Tài nguyên và Môi trường biển trong các năm gần đây tại khu vực này cho thấy nồng độ dầu trong nước biển khá cao đặc biệt là khu vực cảng Cái Lân và vịnh Cửa Lục (hình 2).

Theo Quy chuẩn của Bộ Tài nguyên và Môi trường (QCVN 10:2008) giới hạn cho phép (GHCP) đối với nồng độ dầu mỡ trong nước biển ven bờ bờ là $0,2 \mathrm{mg} / \mathrm{l}$. Đối chiếu 
với các quy chuẩn này cho thấy môi trường nước ở đây đã bị ô nhiễm nghiêm trọng (cao gấp từ 3 - 12 lần GHCP), đặc biệt những khu vực cảng như cảng Cái Lân, Cảng xăng dầu B12 từ đây phát tán ra toàn vịnh Cửa Lục và đổ ra vịnh Hạ Long

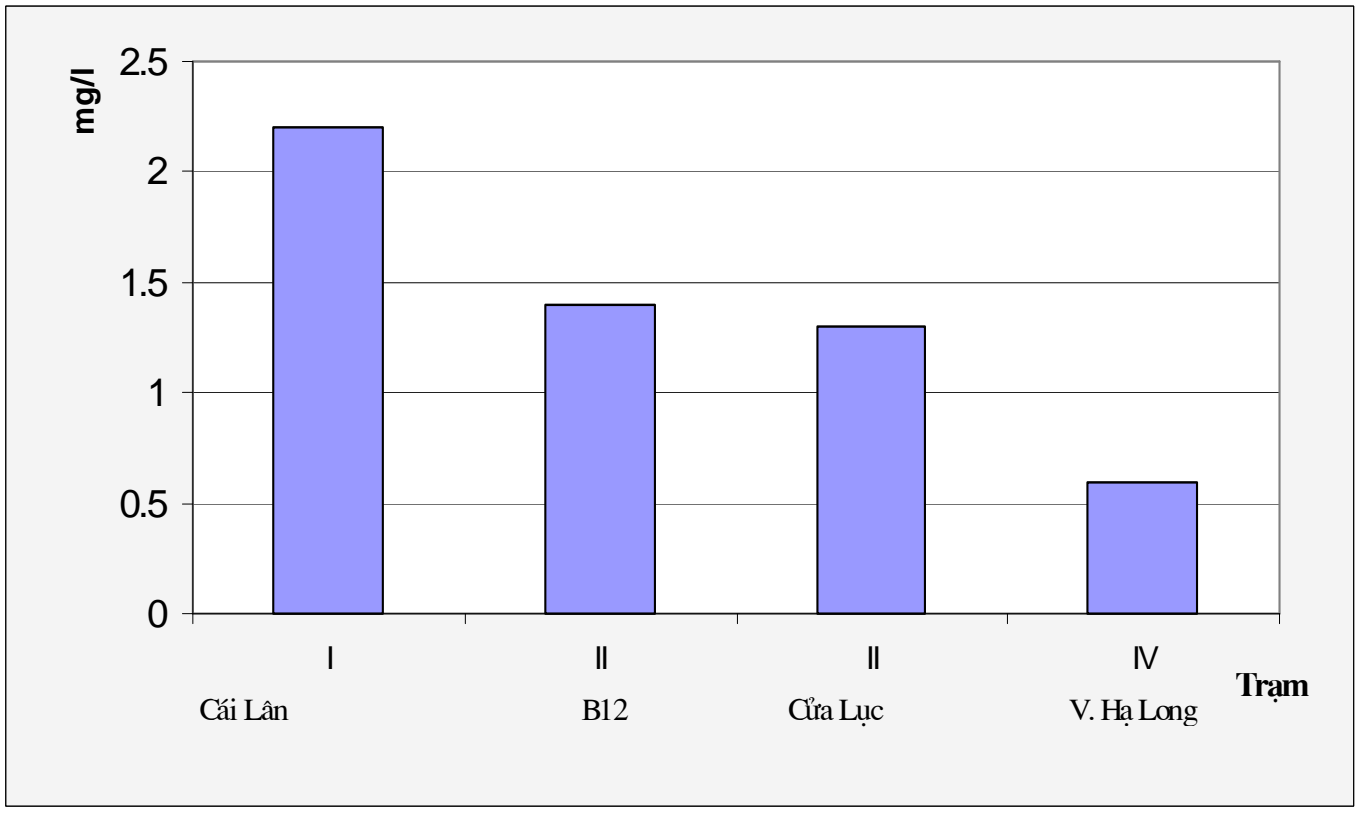

Hình 2: Nồng độ dầu trung bình tại các khu vực trong vịnh Hạ Long và lân cận (DC.Thung, 2009)

Kết quả khảo sát năm 2007, nồng độ dầu trong nước tầng mặt vùng biển vịnh Hạ Long trong mùa khô dao động từ $0,07-2,01 \mathrm{mg} / \mathrm{l}$, trung bình $1,04 \mathrm{mg} / \mathrm{l}$, mùa mưa dao động từ $0,07-2,32 \mathrm{mg} / \mathrm{L}$, trung bình $1,20 \mathrm{mg} / \mathrm{L}$, nồng độ dầu chênh lệch giữa hai mùa không lớn. Nồng độ dầu trong nước thường giảm dần từ bờ ra phía ngoài khơi, cao nhất gần các bến cảng là nơi có mật độ tàu thuyền cao (cửa Lục $1,87-2,01 \mathrm{mg} / \mathrm{l}$ ), thấp nhất khu vực Hang Trai, Cọc Chèo (0,13 mg/l) (hình 3).

Nồng độ dầu trong nước Vịnh Hạ Long các năm từ 2008 đến 2010 dao động từ 0,32 đến $0,75 \mathrm{mg} / \mathrm{l}$. So với QCVN 10:2008, nồng độ dầu cao hơn GHCP từ 1,6 đến 3,7 lần.

Mức độ ô nhiễm dầu thường được đánh giá thông qua hệ số ô nhiễm $\left(\mathrm{T}_{\hat{o} . n}\right)$ đây là tỷ số giữa nồng độ dầu trong nước và nồng độ $\mathrm{GHCP}$ trong nước biển ven bờ $(0.2 \mathrm{mg} / \mathrm{l})$. Theo số liệu thống kê, mức độ ô nhiễm nước bởi dầu tăng lên theo thời gian (bảng 1), năm 1995, hệ số ô nhiễm bằng 0,9 và có xu hướng tăng dần từ năm 1996 đến năm 2010, trong đó năm 2007 có hệ số ô nhiễm rất cao $(9,0)$. Như vậy có thể thấy nồng độ dầu trong nước biển khu vực vịnh Hạ Long đang ở mức báo động và có xu thế tăng dần theo thời gian, điều có có nghĩa là môi trường nước ngày càng trở nên ô nhiễm dầu nặng hơn. 


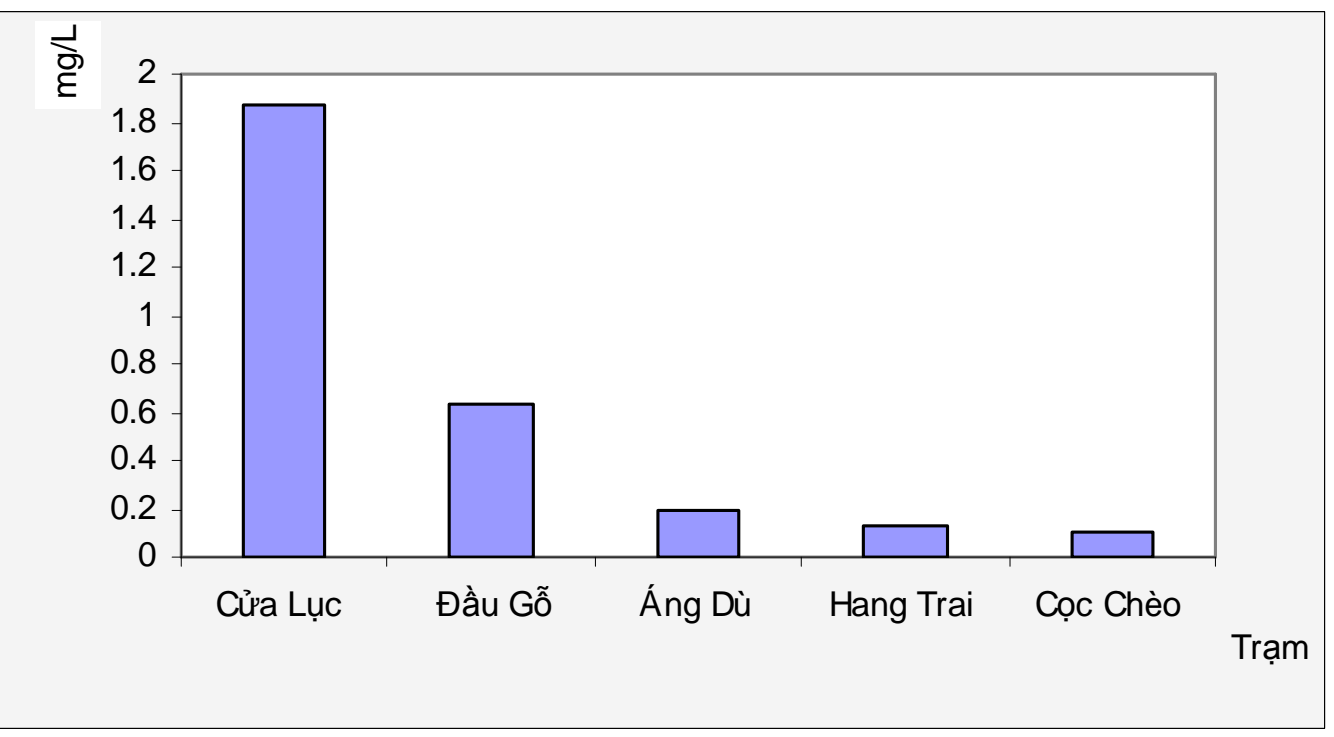

Hình 3: Phân bố dầu từ ven bờ ra ngoài khơi khu vực vịnh Hạ Long năm 2007 (nguồn: DC.Thung 2009)

Bảng 1: Hệ số ô nhiễm dầu trung bình trong nước biển Cửa Lục

\begin{tabular}{|l|l|l|l|l|l|l|l|l|l|}
\hline Khu vực & \multicolumn{10}{|c|}{ Năm } \\
\hline & 1995 & 1996 & 1997 & 1998 & 1999 & 2000 & 2001 & $2007^{*}$ & $2010^{* *}$ \\
\hline Cửa Lục & 0,9 & 2,1 & 1,6 & 2,0 & 2,5 & 2,7 & 2,7 & 9,0 & 3,7 \\
\hline
\end{tabular}

(Nguồn: Trạm quan trắc quốc gia, *: DCThung 2009, **: ĐT Ô nhiễm dầu)

Trước năm 1995 khi các hoạt động cảng, vận tải, du lịch chưa phát triển khu vực Vịnh Hạ Long có rạn san hô rất phát triển, phân bố rải rác hầu khắp quanh các đảo đá trong vùng vịnh. Các kết quả nghiên cứu về rạn san hô ở khu vực này cho thấy rạn san hô có tính đa dạng sinh học cao thể hiện qua mức độ phong phú về số lượng giống loài hiện hữu tại khu vực. Có đến 153 loài, 44 giống, 12 họ san hô cứng và khoảng 20 loài san hô mềm và san hô sừng được tìm thấy trong khu vực (Yết, 1999). Tuy các rạn san hô ở đây không lớn do địa hình chia cắt song chúng có độ phủ khá cao, có 33,3\% số rạn thuộc loại tốt (độ phủ san hô sống trên $50 \%$ ), 41,7\% số rạn thuộc loại trung bình (độ phủ san hô từ $25-50 \%)$, và chỉ có $25 \%$ số rạn thuộc nhóm nghèo nàn $(<25 \%)$. 
Cùng với sự gia tăng của mức độ ô nhiễm dầu từ năm 1998 trở lại đây, các rạn san hô ở khu vực này đang ngày càng suy giảm về số lượng loài, độ phủ và phạm vi phân bố. Kết quả khảo sát tại hiện trường và phân tích mẫu vật được trong năm 2009 và 2010 trên toàn khu vực Hạ Long chỉ còn tìm thấy 102 loài, 32 giống thuộc 11 họ của bộ san hô cứng. Như vậy, so với những năm trước số loài đã bị suy giảm đến 1/3 (33\%). Hiện nay ở khu vực Hạ Long không còn rạn nào thuộc loại rạn tốt, chỉ còn lại các rạn có độ phủ thuộc loại trung bình đến nghèo nàn. Nhìn chung trên các rạn có tỷ lệ đá san hô chết rất cao, toàn bộ đới mặt bằng trên tất cả các rạn đều bị chết - nơi có khả năng tiếp xúc với dầu nhiều hơn.

Như vậy, cùng với sự gia tăng về các hoạt động du lịch, cảng, giao thông thủy... nồng độ dầu trong nước biển khu vực Hạ Long cũng ngày càng tăng. Có thể dễ dàng nhận thấy nồng độ dầu trong nước biển tỷ lệ nghịch với sự phân bố và đa dạng của san hô theo không gian.Đặc biệt quanh các khu vực bến tàu, cảng, những nơi tàu thuyền hoạt động nhiều có nồng độ dầu trong nước cao thì không có san hô phân bố hoặc san hô đã chết như khu vực Đầu Gỗ, ven bờ Bãi Cháy, Hồng Gai, Cửa Lục...

Dầu tác động của dầu đến hệ sinh thái rạn san hô bằng nhiều cơ chế khác nhau như tạo thành màng mỏng phủ trên mặt nước ngăn cản sự trao đổi khí giữa nước và không khí dẫn đến môi trường thiếu ôxy, các sinh vật sống trong môi trường này không lấy được ôxy để thực hiện quá trình trao đổi chất và chết. Khi thủy triều rút dầu bám trực tiếp trên bề mặt san hô làm san hô bị ngộ độc hoặc sốc gây chết san hô. Hoặc khi nồng độ dầu trong nước cao san hô sẽ liên tục tiết chất nhờn để ngăn cản hoặc đào thải dầu bám vào chúng dẫn đến chúng bị kiệt sức và chết. Ngoài ra dầu nồng động dầu trong nước cao, kéo dài còn làm ảnh hưởng đến quá trình sinh sản, tiêu hóa, tập tính của san hô làm chúng không phát triển và chết dần.

\section{Tác động của ô nhiễm dầu đến rạn san hô khu vực Cù Lao Chàm}

Kết quả khảo sát vào tháng $1 / 2008$ cho thấy nồng độ dầu trong nước khu vực Cù Lao Chàm tại tầng mặt dao động từ $0,4-3,82 \mathrm{mg} / \mathrm{l}$, trung bình $2,11 \mathrm{mg} / \mathrm{l}$. Tại tầng đáy nồng độdầu trong nước dao động từ 0,38 - 1,68 mg/l, trung bình $1,03 \mathrm{mg} / \mathrm{l}$. Nếu so sánh với quy chuẩn chất lượng nước biển ven bờ của Bộ Tài nguyên và Môi trường cho nước biển ven bờ là $0,2 \mathrm{mg} / \mathrm{l}$ cho thấy trong năm 2008 vùng biển Cù Lao Chàm đã bị ô nhiễm dầu nặng, tại tầng mặt vượt GHCP 10.5 lần và tầng đáy vượt GHCP 5 lần (Thạnh 2008).

Hệ số ô nhiễm dầu trong nước tháng 1/2008 so với những năm trước tăng lên nhiều lần. Khi không có sự cố tràn dầu, mức độ ô nhiễm dầu trong vùng biển khá thấp, hệ số ô nhiễm dao động từ $0,1-1,8$, khi có sự cố tràn dầu hệ số ô nhiễm dao động từ 1,9 - 19,0, hệ 
số ô nhiễm dầu tăng cao gấp 19 lần điều này chứng tỏ nước ở vùng biển Cù Lao Chàm bị ô nhiễm dầu nặng (bảng 2).

Bảng 2: Hệ số ô nhiễm dầu tại một số khu vực ở Cù Lao Chàm (Thạnh, 2008)

\begin{tabular}{|c|c|c|c|}
\hline Khu vực thu mẫu & $\mathbf{2 0 0 2}$ & $\mathbf{2 0 0 3}$ & $\mathbf{2 0 0 8}$ \\
\hline Khu vực Hòn Mồ & 0.3 & - & 4.6 \\
\hline Khu vực Hòn Giai & 0.1 & - & 1.9 \\
\hline Khu vực Bãi Hương & 1.3 & 1.8 & 6.7 \\
\hline Mặt cắt II & 0.7 & 1.0 & 5.4 \\
\hline Mặt cắt III & 1.2 & 0.4 & 19.0 \\
\hline
\end{tabular}

Như vậy có thể thấy xu thế của nồng độ dầu trong nước biển Cù Lao Chàm tăng dần theo thời gian, đặc biệt cao đột biến vào đầu năm 2008 do hiện tượng dầu tràn không rõ nguồn gốc và đắm tàu gần đó từ năm 2007. Cũng thời điểm này tiến hành khảo sát trên 2 rạn san hô là Bãi Bắc và Bãi Hương cho thấy đã có sự thay đổi lớn về thành phần loài và cấu trúc khu hệ. Các năm trước rạn bãi Bắc là một trong các rạn đẹp nhất tại khu vực Cù Lao Chàm với sự thống trị của các loài san hô cành, dạng bàn Acropora phát triển mạnh trải dài và rộng trong khoảng độ sâu từ 1 đến $5 \mathrm{~m}$ với độ phủ lên đến 70 - $80 \%$ phía trên $0,5-1,5 \mathrm{~m}$ là sự thống trị của Montipora cành với độ phủ $90-100 \%$. Tuy nhiên trong lần khảo sát năm 2008, các thảm san hô này không còn nữa mà thay vào đó là đá san hô chết. Số lượng loài thuộc họ Faviidae tăng lên với nhiều tập đoàn dạng khối nhỏ phân bố rải rác trong đới san hô chết mà trước kia Acroporidae chiếm ưu thế. Phía chân rạn có nhiều tập đoàn Porites dạng khối lớn sống chết xen kẽ, dưới nền đáy là sự phổ biến là san hô mềm. Rạn Bãi Hương không có sự thay đổi đáng kể về san hô mềm nhưng đối san hô cứng mật độ giảm đi rất nhiều, thảm san hô cành Montipora ở độ sâu $0,5-1,5 \mathrm{~m}$ đã chết toàn bộ, các tập đoàn sau hô khối ở độ sâu $2-4 \mathrm{~m}$ cũng bị chết nhiều. Hiện tại rạn Bãi Hương còn lại là quần xã san hô mềm rất phát triển ở độ sâu 4-8m . Kết quả khảo sát cũng cho thấy rạn Bãi Bắc có tỷ lệ san hô sống thấp, chỉ có $10 \%$ là san hô cứng và $7,5 \%$ là san hô mềm, trong khi đó tỷ lệ đá san hô chết và đá rất cao chiếm trên $60 \%$ tổng hợp phần đáy. Rạn Bãi Hương cũng tương tự, hầu như không có san hô cứng $(0,6 \%)$ trong khi đó hợp phần đá ở rạn này rất cao chiến đến gần $1 / 2$. San hô mềm có độ phủ khá cao ( $20 \%$ trong hợp phần đáy) (bảng 3). 
Bảng 3: Độ phủ san hô và các hợp phần khác tại rạn Bãi Bắc và Bãi Hương (\%) (Ngải, 2009)

\begin{tabular}{|c|c|c|}
\hline Chất đáy & Bãi Bắc & Bãi Hương \\
\hline San hô cứng (HC) & 10 & 0.6 \\
\hline San hô mềm (SC) & 7.5 & 20.6 \\
\hline San hô mới chết (RKC) & 0 & 0 \\
\hline Đá san hô (DC) & 20 & 0 \\
\hline Rong lớn (FS) & 0 & 0 \\
\hline Hải miên (SP) & 0 & 48.7 \\
\hline Đá (RC) & 40.6 & 0.6 \\
\hline Vụn san hô (RB) & 0 & 13.9 \\
\hline Cát (SD) & 3.1 & 10.5 \\
\hline Bùn (SI) & 16.2 & 0 \\
\hline Khác (OT) & 2.5 & \\
\hline
\end{tabular}

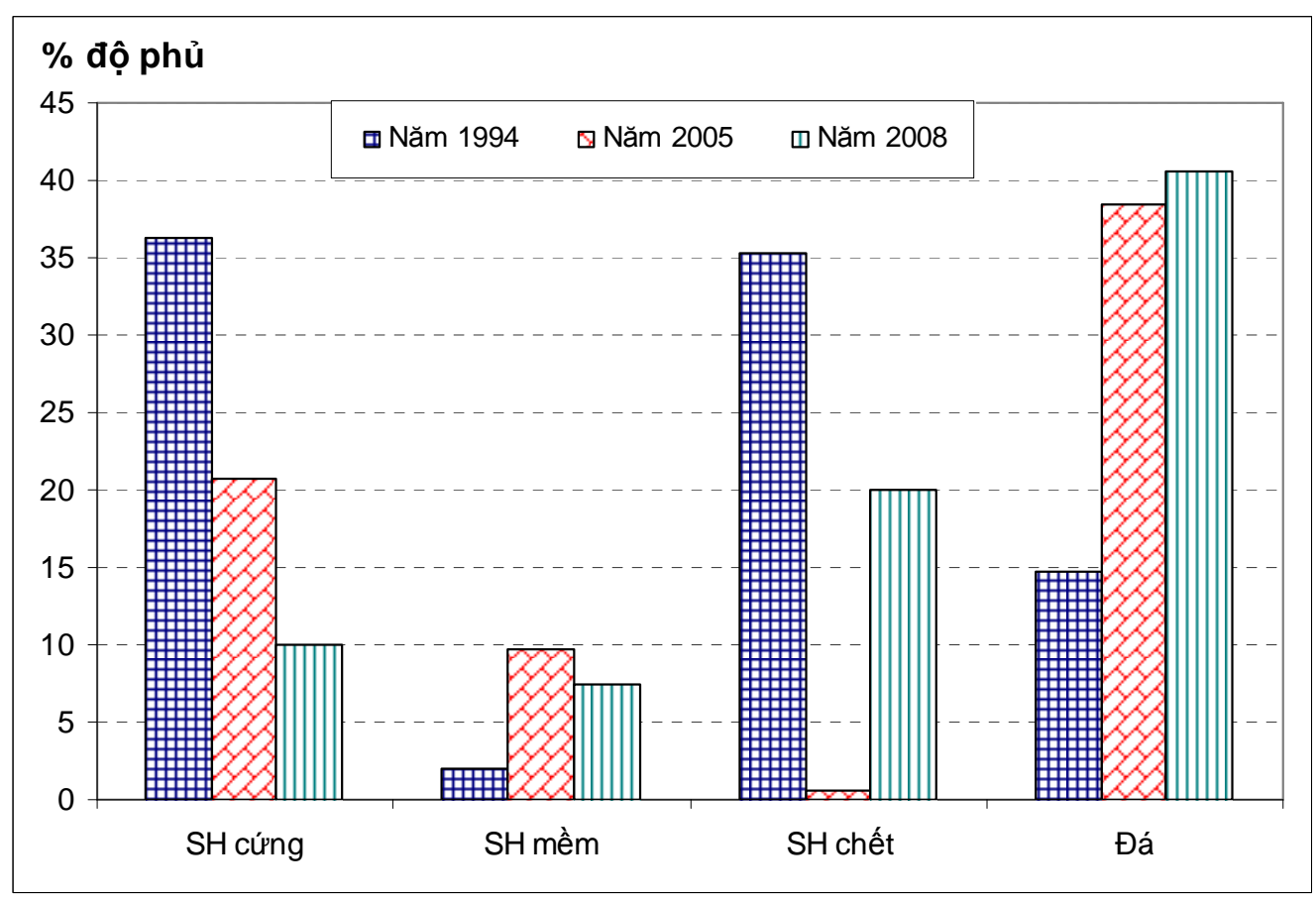

Hình 4: Hợp phần chất đáy từ năm 1994 đến 2008 tại rạn Bãi Bắc 
So sánh kết quả khảo sát độ phủ lần này với các kết quả khảo sát độ phủ san hô của WWF (1994) và Ngải (2009) trong các năm 1994, 2005 và 2008 tại hai rạn Bãi Bắc và Bãi Hương cho thấy có sự thay đổi lớn về tỷ lệ \% độ phủ san hô sống. Hợp phần san hô cứng ít đi trong san hô chết, đá và bùn lại tăng lên, chỉ có san hô mềm là tương đối ổn định. Như vậy có thể nói sự suy giảm độ phủ san hô ở khu vực này đã đến mức báo động (mất khoảng 60\% -80\%) (hình 4 và 5).

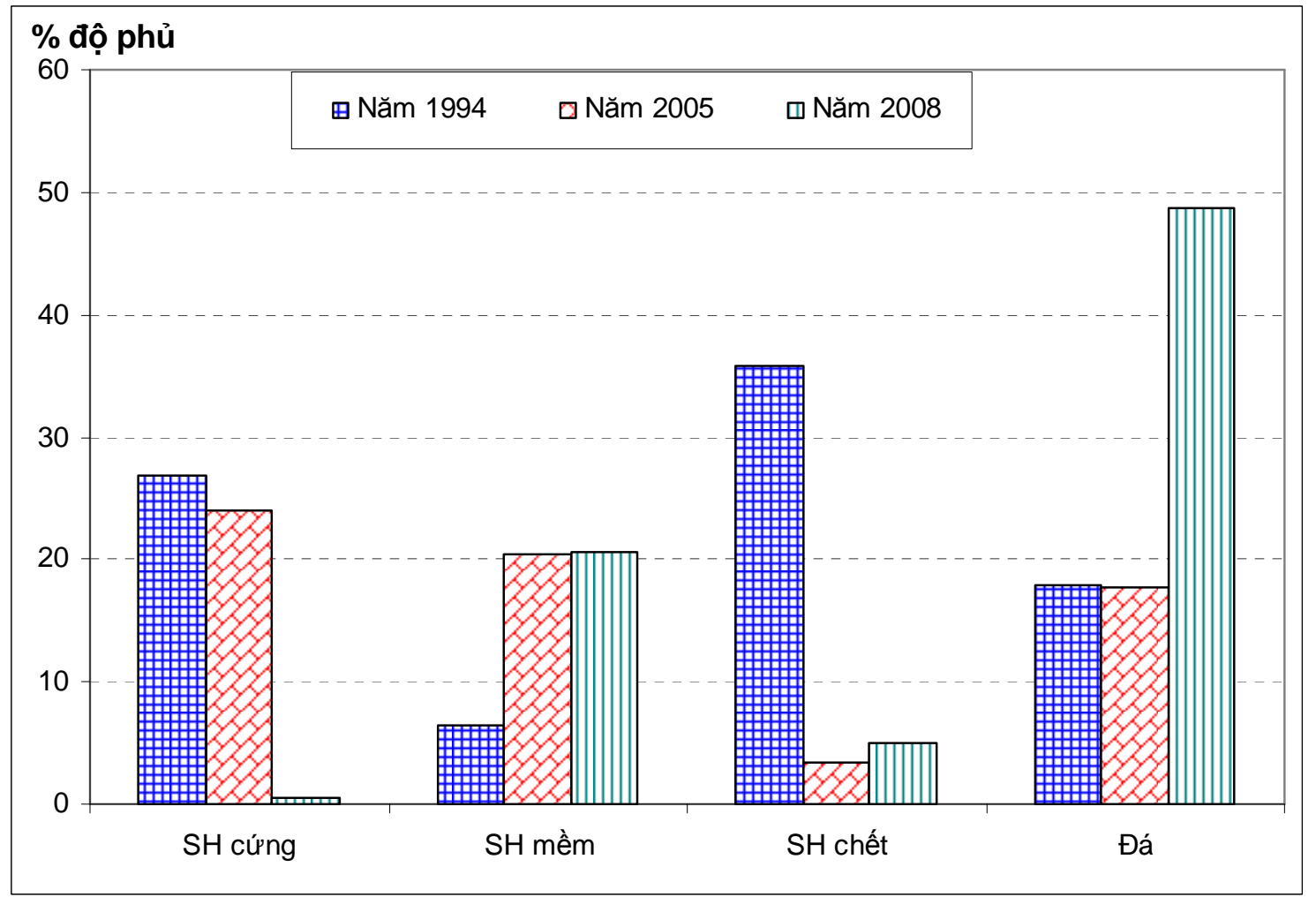

Hình 5: Hợp phần chất đáy tại rạn Bãi Hương từ năm 1994 đến 2008

Nguyên nhân dẫn đến sự suy giảm đó có thể liên quan đến nồng độ dầu trong nước biển tăng cao. Đầu năm 2007, dọc ven biển Việt Nam đã phát hiện có nhiều vết dầu loang tấp vào bờ vón thành cục, vùng biển Cù Lao Chàm là nơi đầu tiên phát hiện ra hiện tượng đó sau đó đến nhiều địa phương khác. Mặc dù thời gian khảo sát đã cách thời điểm xảy ra sự cố tràn dầu gần 1 năm nhưng nồng độ dầu trong nước biển của khu vực vẫn ở mức rất cao, cao hơn GHCP hàng chục lần. Do vậy tại mức này đã ảnh hưởng rất lớn đến đời sống của các sinh vật dưới nước, nếu như trong lúc xảy ra sự cố thì nồng độ dầu trong nước chắc chắn còn cao hơn nhiều lần nữa. 


\section{Tác động của ô nhiễm dầu đến rạn san hô khu vụ̣c Phú Quốc}

Kết quả phân tích mẫu thu được trong các chuyến khảo sát năm 2009 và 2010 trên các rạn san hô thuộc quần đảo An Thới đã ghi nhận được 86 loài thuộc 33 giống san hô cứng, 1 loài san hô thuỷ tức và 8 loài san mềm và san hô sừng. Như vậy so với kết quả khảo sát của WWF (1994) thì số lượng loài không có biến động nhiều chứng tỏ khu vực này có môi trường khá ổn định, đồng thời công tác bảo vệ của chính quyền địa phương cũng phát huy hiệu quả khá tốt trong thời kỳ phát triển du lịch lặn và khai thác huỷ hoại tài nguyên như hiện nay. Các rạn san hô tại khu vực An Thới còn khá tốt, trong các rạn được khảo sát trước đây có $25 \%$ rạn san hô tại Phú Quốc ở trong tình trạng tốt, 58,3\% trong trạng thái trung bình và $16,7 \%$ rạn san hô trong tình trạng xấu (bảng 4). Các nhóm loài phổ biến được ghi nhận trên các rạn là Acropora, Porites, Pavona, Montipora.

Bảng 4: Độ phủ san hô tại các rạn khảo sát năm 2009

\begin{tabular}{|c|c|c|c|c|c|}
\hline & $\begin{array}{c}\text { Hòn } \\
\text { Xưởng }\end{array}$ & Gầm Ghì & $\begin{array}{c}\text { Hòn } \\
\text { Thơm }\end{array}$ & Hòn Roi & $\begin{array}{c}\text { Trung } \\
\text { bình }\end{array}$ \\
\hline San hô cứng & 50 & 67.5 & 28.7 & 52.5 & 49.7 \\
\hline San hô mềm & 0.6 & 0 & 1.2 & 0.5 & 0.6 \\
\hline San hô mới chết & 0 & 0 & 0 & 1 & 0.2 \\
\hline Đá san hô chết & 6.9 & 0.6 & 6.2 & 9 & 5.7 \\
\hline Rong lớn & 0 & 0 & 0 & 0 & 0 \\
\hline Hải miên & 1.9 & 2.5 & 2.5 & 1 & 2.0 \\
\hline Đá & 16.2 & 8.1 & 40 & 17.5 & 20.4 \\
\hline Vụn san hô & 3.7 & 2.5 & 1.2 & 2 & 2.3 \\
\hline Cát & 19.4 & 17.5 & 13.7 & 15 & 16.4 \\
\hline Bùn & 0 & 0 & 0 & 0 & 0 \\
\hline Các nhóm khác & 1.2 & 1.2 & 6.2 & 1.5 & 2.5 \\
\hline
\end{tabular}

Trong chuyến khảo sát năm 2010 phát hiện thấy rất nhiều tập đoàn san hô mới chết vẫn còn lộ bộ xương còn trắng, đồng thời có rất nhiều tập đoàn bị mất màu trong đó có những khối san hô dạng khối Porites đường kính $2-3 \mathrm{~m}$. Đây là những khối san hô có tuổi đời hàng trăm năm, chúng rất có ý nghĩa trong việc tạo ra các tiểu sinh cảnh cho sinh 
vật biển trú ngụ và nghiên cứu cổ khí hậu. Kết quả khảo sát lặp lại trên mặt cắt cố định tại 3 rạn cho thấy tỷ lệ san hô cứng giảm gần 1/2 ở Hòn Xưởng và Hòn Gầm Ghì, trong khi san hô mới chết và đá san hô chết có tỷ lệ cao và tăng nhiều so với năm 2009 (bảng 5).

Bảng 5: Độ phủ san hô tại các rạn khảo sát năm 2010

\begin{tabular}{|c|c|c|c|}
\hline & Hòn Xưởng & Gầm Ghì & Hòn Thom \\
\hline San hô cứng & 29.375 & 36.875 & 25.625 \\
\hline San hô mềm & 0.625 & 0 & 0 \\
\hline San hô mới chết & 8.75 & 5.625 & 4.375 \\
\hline Đá san hô chết & 15.625 & 11.875 & 25 \\
\hline Rong lớn & 0 & 0 & 0 \\
\hline Hải miên & 0 & 0.625 & 0.625 \\
\hline Đá & 26.25 & 10.625 & 28.75 \\
\hline Vụn san hô & 0 & 0 & 0 \\
\hline Cát & 19.375 & 34.375 & 12.5 \\
\hline Bùn & 0 & 0 & 1.875 \\
\hline Các nhóm khác & 0 & 0 & 1.25 \\
\hline
\end{tabular}

Khu vực quần đảo An Thới là nơi tập trung tàu thuyền của ngư dân đánh bắt xa bờ, tàu thuyền du lịch và cảng hàng hóa do vậy lượng dầu rò rỉ ra môi trường biển khá nhiều. Kết quả phân tích mẫu thu được vào tháng 6/2009 tại khu vực cảnh An Thới và ven các đảo thuộc quần đảo An Thới cho thấy khu vực gần cảng mức độ ô nhiễm dầu cao hơn GHCP 5 lần, càng xa bờ nồng độ dầu càng thấp đi. Trong khi đó khu vực Hòn Dừa (gần cảng An Thới nhất) chỉ phát hiện thấy có 15 loài san hô (số lượng loài rất thấp), tiếp đến là hòn Roi có 17 loài, còn lại các đảo xa hơn như Hòn Thơm, Hòn Xưởng, Gầm Ghi có số loài từ 31 đến 49 loài. Sự biến động về số lượng loài ở đây có thể liên quan đến mức độ ô nhiễm dầu của khu vực này.

\section{KẾT LUẬN}

- Tình hình ô nhiễm dầu tại các cảng biển, bến tàu vùng ven biển Việt Nam nói chung và tại 3 khu vực nghiên cứu nói riêng đã đến mức báo động. Không chỉ ở những khu vực ven bờ mà kể cả ở những vùng đảo xa như Phú Quốc cũng bị ô nhiễm bởi dầu. 
Nồng độ dầu luôn ở mức cao từ 1,3 đến 19 lần GHCP. Với nồng độ đó đã ảnh hưởng rất lớn đến môi trường và đời sống của các loài thủy sinh vật nói chung và san hô nói riêng. Nhiều loài sinh vật nhạy cảm có thể bị chết hoặc di chuyển đến nơi khác làm xáo trộn và có thể gây mất cân bằng sinh thái trong khu vực.

- Sự suy giảm số lượng loài, độ phủ và phân bố của san hô đã diễn ra trong những năm gần đây có thể liên quan đến mức độ ô nhiễm dầu. Ở khu vực gần cảng, bến tầu, nồng độ dầu rất cao, càng ra xa nồng độ dầu càng giảm dần trong khi san hô phân bố nhiều ở những nơi có nồng độ dầu thấp và giảm dần ở những nơi có nồng độ dầu cao.

- Sự suy giảm của san hô rõ nhất sau sự cố tràn dầu năm 2007 ở khu vực Cù Lao Chàm. Nồng độ dầu trong nước cao lên đột biến trong khi các rạn san hô thay đổi hẳn về cấu trúc, số lượng loài và độ phủ.

\section{TÀI LIỆU THAM KHẢO}

1. Cục Hàng hải Việt Nam, 2010. Dự thảo báo cáo "Tình hình tác động môi trường lĩnh vực hàng hải giai đoạn 2006 - 2010 và xây dựng kế hoạch giảm thiểu ô nhiễm giai đoạn 2011 - 2020.

2. Nguyễn Đăng Ngải, 2009. Sự suy thoái san hô Cù Lao Chàm, nguyên nhân và tác động. Tạp chí khoa học và công nghệ biển. ISSN 1859-3097. Tr. 250-261.

3. Đinh Thị Ngọ, 2010. Hóa học mỏ và dầu khí. NXB Khoa học và Kỹ thuật, 252 tr.

4. Trần Đức Thạnh, Đỗ Công Thung và nnk, 2008. Điều tra, khảo sát đánh giá thiệt hại về kinh tế, môi trường và ảnh hưởng đến các hệ sinh thái biển, đề xuất biện pháp trước mắt và lâu dài để phục hồi môi trường các khu vực bị ô nhiễm dầu tại Cù Lao Chàm và Cửa Đại (tỉnh Quảng Nam). Báo cáo đề tài. Lưu trữ tại Viện TN\&MTB.

5. Đỗ Công Thung và nnk, 2009. Nghiên cứu các giá trị đa dạng sinh học vịnh Hạ Long phục vụ cho việc quản lý, phát huy giá trị đa dạng sinh học của Di sản. Báo cáo tổng kết đề tài. Lưu trữ tại Viện TN\&MTB.

6. Nguyễn Văn Tiến, 2007. Điều tra nguồn lợi san hô và thảm cỏ biển Phú Quốc 2005 $-2007$.

7. Trạm Quan trắc và Phân tích môi trường Biển miền Bắc, 2004 - 2010. Tập báo cáo quý và báo cáo tổng kết hàng năm. Tài liệu lưu giữ tại Viện Tài nguyên và Môi trường Biển. 
8. Võ Sĩ Tuấn và nnk, 2006. Hệ sinh thái rạn san hô viển Việt Nam. NXN Khoa học và Kỹ thuật. 212tr.

9. WWF Vietnam Marine Conservation Northern Survey Team, 1994. Survey report on the Biodiversity, Resource Utilization and Conservation Potential of $\mathrm{Cu}$ Lao Cham and Adjacent Islands, Quang Nam Da Nang Province, Central Viet Nam.

10. WWF Vietnam Marine Conservation Northern Survey Team, 1994. Survey report on the Biodiversity, Resource Utilization and Conservation Potential of An Thoi Islands, Kien Giang Province, Viet Nam.

11. Nguyễn Huy Yết, 1999. Điều tra, nghiên cứu sự suy thoái san hô ở vùng biển ven bờ phía Bắc, đề xuất các giải pháp bảo vệ và phục hồi. Báo cáo tổng kết đề tài cấp Viện KH\&CNVN. Lưu trữ tại Viện TN\&MTB.

12. Nguyễn Huy Yết, Nguyễn Thị Thu và nnk, 2010. Đánh giá mức độ suy thoái các hệ sinh thái ven bờ biển Việt Nam và đề xuất các giải pháp quản lý bền vững. Đề tài cấp Nhà nước giai đoạn 2009 - 2010.

\title{
EFFECTABLE OF OIL POLLUTION TO CORAL REEFS IN THE COASTAL AREAS OF VIETNAM
}

\section{NGUYEN DANG NGAI}

\begin{abstract}
Summary: In the study areas (Ha Long, Cu Lao Cham, Phu Quoc) oil concentration were high, exceeding the Vietnam's Standard for coastal water (QCVN 10:2008) from 1.3 to 19 times. Thus, these areas have been a sign of oil pollution and directly impacted on aquatic organisms. The decline in the number of species, coverage and distribution of coral has occurred in recent years that may be related to oil pollution levels. After the oil spill event in 2007 at Cu Lao Cham Islands, oil concentration in the water was suddenly high while the coral reefs seriously change in the structure, number of species and coverage. The decline of coral reefs also varied following the oil concentration in water, in near port and harbor areas where oil concentration is very high and lower in the distant areas whereas coral reefs thrive in low oil concentration and decrease in areas with high oil concentration.
\end{abstract}

Ngày nhận bài: 24 - 3 - 2011

Ngưòi nhận xét: PGS. TS. Đỗ Công Thung 